\title{
Exceptional new record of Cretaceous Hauterivian Angiospermid Pollen from Southern England
}

\author{
N.F. HUGHES, A.B. McDOUGALL and J.L. CHAPMAN \\ University Department of Earth Sciences, Downing Street, Cambridge, CB2 3EQ, England
}

\begin{abstract}
Routine SEM examination of a previously neglected part of the Wealden succession in the borehole at Kingsclere, Southem England, has revealed a very well preserved set of specimens, in a single sample (KCE 777), of a type of early pollen grain only known hitherto from isolated grains. This tectate-columellate monosulcate pollen with sharply segmented muri and sturdy columellae is the earliest known with generally accepted angiospermid characters, and appears to be of Cretaceous Hauterivian age. The nature of the simple tectate pattern over the aperture suggests a style of pollen development to bear in mind when searching for even earlier pollen of this group.
\end{abstract}

\section{INTRODUCTION}

Although the Kingsclere borehole sample KCE 475 (borehole depth in feet) was originally used by Couper (1958) to erect the taxon Clavatipollenites hughesil, and was restudied by $\mathrm{Kemp}$ (1968) to amplify that taxon, it was not until SEM scan-search was applied (Hughes, Drewry and Laing 1979) that it was fully realised that this and adjacent rich samples (KCE 469 to $\mathrm{KCE}$ 475) of late Barremian to early Aptian age (Kemp 1970) contained not one but seven or more diverse monosulcate or trichotomosulcate taxa of angiospermid pollen in reasonable abundance. Even with light microscopy Kemp (1968, p.428) recorded some doubts on the homogeneity of this early taxon.

Subsequent similar studies of continuous rock successions have led to knowledge of a diverse Barremian pollen succession (Hughes and McDougall, 1990) in the Dorset and Isle of Wight, London (Warlingham borehole) and the Norfolk-Lincolnshire areas, and to recognition of a late Hauterivian age for the earliest samples discovered (Hughes and McDougall 1987); when this last paper was written however, the earliest angiospermid pollen grains known were all single specimens of striking appearance but collected from scattered localities and therefore subject to caution in interpretation.

The present paper is concerned with an unusually fine record discovered during examination of samples not previously studied (KCE 682 - KCE 787) from deep in the Kingsclere borehole (details of locality with record). In sample KCE 777 is a set of ten specimens of a pollen type only known previously from a single specimen from the Warlingham borehole (sample WM 1488/7 of Hauterivian age).

\section{POLLEN DESCRIPTION}

The ten specimens of the Group Retisulc pollen (Hughes, 1989) were observed on two stubs (AM 592, 593) fitted with Mark 3 Cambridge Grids, and made up from preparation Y391 of the Kingsclere sample KCE 777 . The record is registered as the palaeotax on HAUTERIVIAN-COLTHICK, with all details entered (Fig. 1) on a Palaeotaxon Record Form (PTR; see Hughes 1989). All ten specimens (A-K) have been used in description, and figures of seven are included in the adjacent plates. Of the material recorded, Specimen $\mathrm{C}$ (Plate 1) displays both the aperture sculpture and the baculae within the lumina; Specimen E (Plate 3) and $F$ (Plate 2) further define and illustrate the aperture. Specimen A (Plate 1 ) illustrates the bottle-shaped columellae, and specimens $H$ and $J$ (Plate 2) the segmentation of the muri. Specimen K (Plate 2) appears to be a variant with open larger lumina and narrow muri, but the columellae are of the same type. Specimens B, D and $\mathrm{G}$ are not figured here.

The palynomorph assemblage (see Plate 3) is unusual; the composition is $98 \%$ trilete spores (of which $37 \%$ are Pilosisporites, $24 \%$ Concavissimisporites and $37 \%$ smooth spores) and some individual grains of Cicatricosisporites. Aequitriradites, 'Ephedripites', CfA Hauterivian-cactisulc 1987 and Podocarpidites were also encountered, but no other bisaccates nor any Classopollis were seen in this rich sample yielding 200 palynomorphs to a single light microscope traverse.

The previously published single specimen record $\mathrm{CfB}$ Retisulc-muriverm (Hughes and McDougall, 1987) from the Warlingham borehole (WM 1488/7) is similar to the new fossils. This specimen is now re-recorded (Fig. 2) below as CfA HAUTERIVIAN-COLTHICK on a Palaeontologic Data-Handling Code form GOR (Hughes, 1989); such re-arrangements of records are deliberately provided for to accommodate new knowledge. and in such a case the old record is superseded but referenced.

\section{STRATIGRAPHIC CORRELATION}

As indicated in Fig.3, the refrence succession is that of the Warlingham borehole, Surrey, in which the sample WM 1416 contained dinocysts of latest Hauterivian age (Hughes and McDougall, 1987).

The Kingsclere sample $\operatorname{KCE} 777$, within the succession $\mathrm{KCE} 787$ to $\mathrm{KCE} 763$, is taken to correspond approximately in the Warlingham borehole to the succession from WM 1488/7 to WM 1446/6. In these beds in both successions are recorded, as well as the new pollen grain, the first 'Ephedripites', the first Retisulcperfotect, an incoming of dinocysts and a lack of any other retisulc pollen. These palynevents do not occur in the same order in the two successions but have been taken in total to represent probable time-correlation between the groups of samples; the numbers of specimens involved are low in all these samples and it seems reasonable therefore to group them together in this way. 


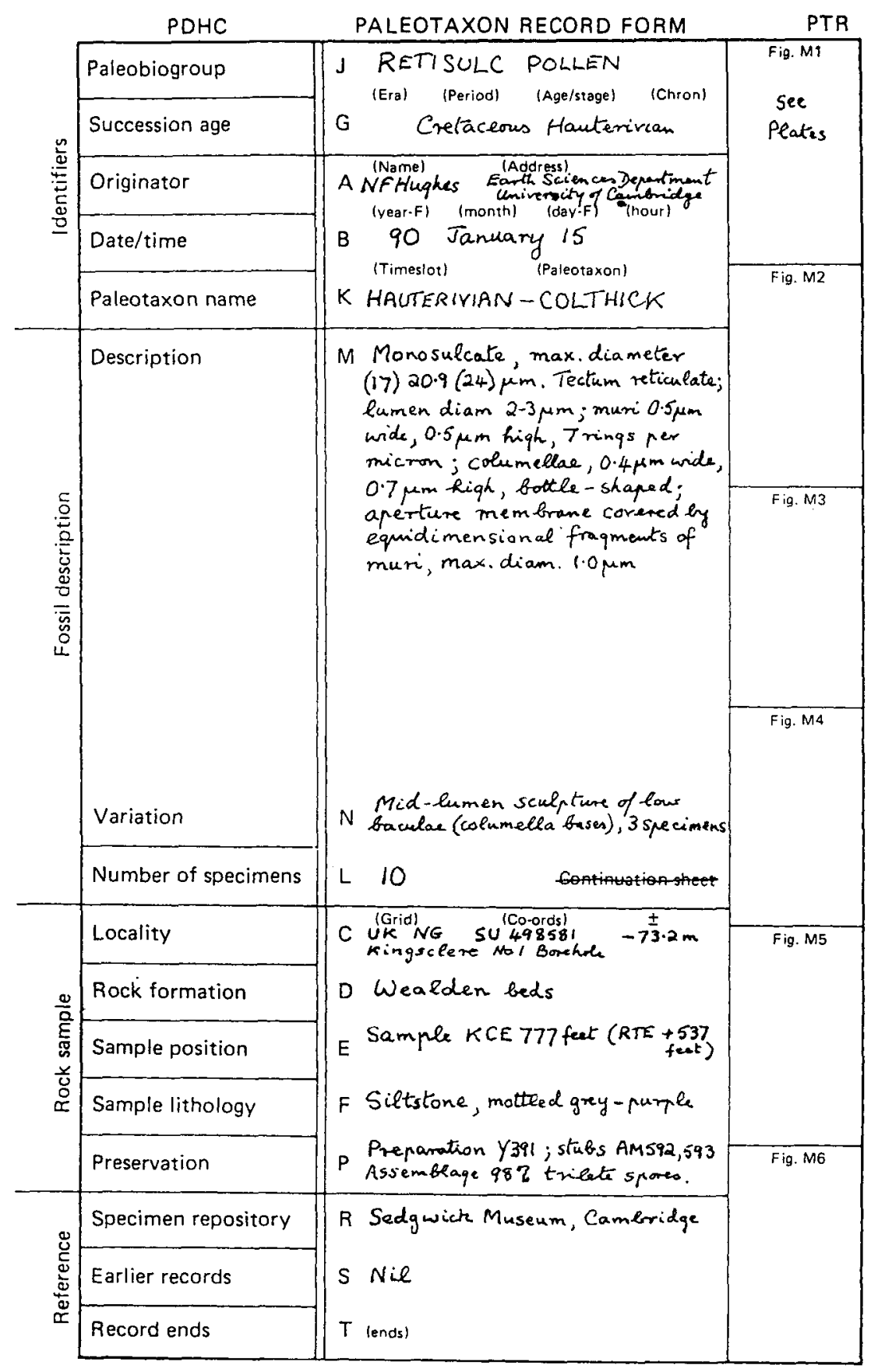

Fig. 1. Palaeotaxon record (PTR form) for pollen Retisulc-Hauterivian-colthick.

\section{Explanation of Plate 1}

Palaeotaxon Hauterivian-Colthick: scale bars 1 micron; 10 microns Figs 3 and 6.

Figs 1-5. Specimen C; stub AM592-307750. 1, 2, 5, 60 ${ }^{\circ}$ tilt.

Figs 6-9. Specimen A; stub AM592-292771. 7, rotated $30^{\circ}$. 

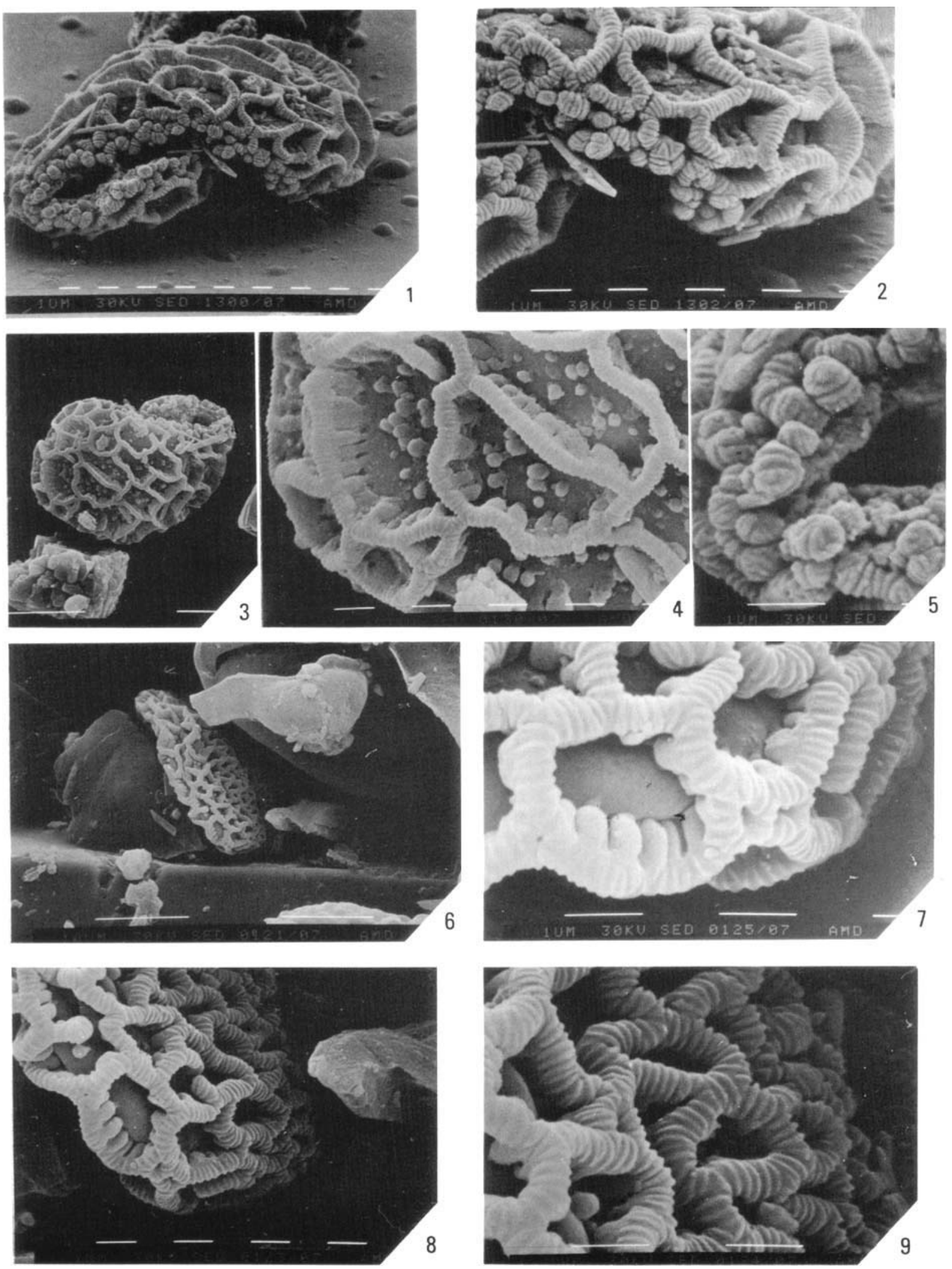


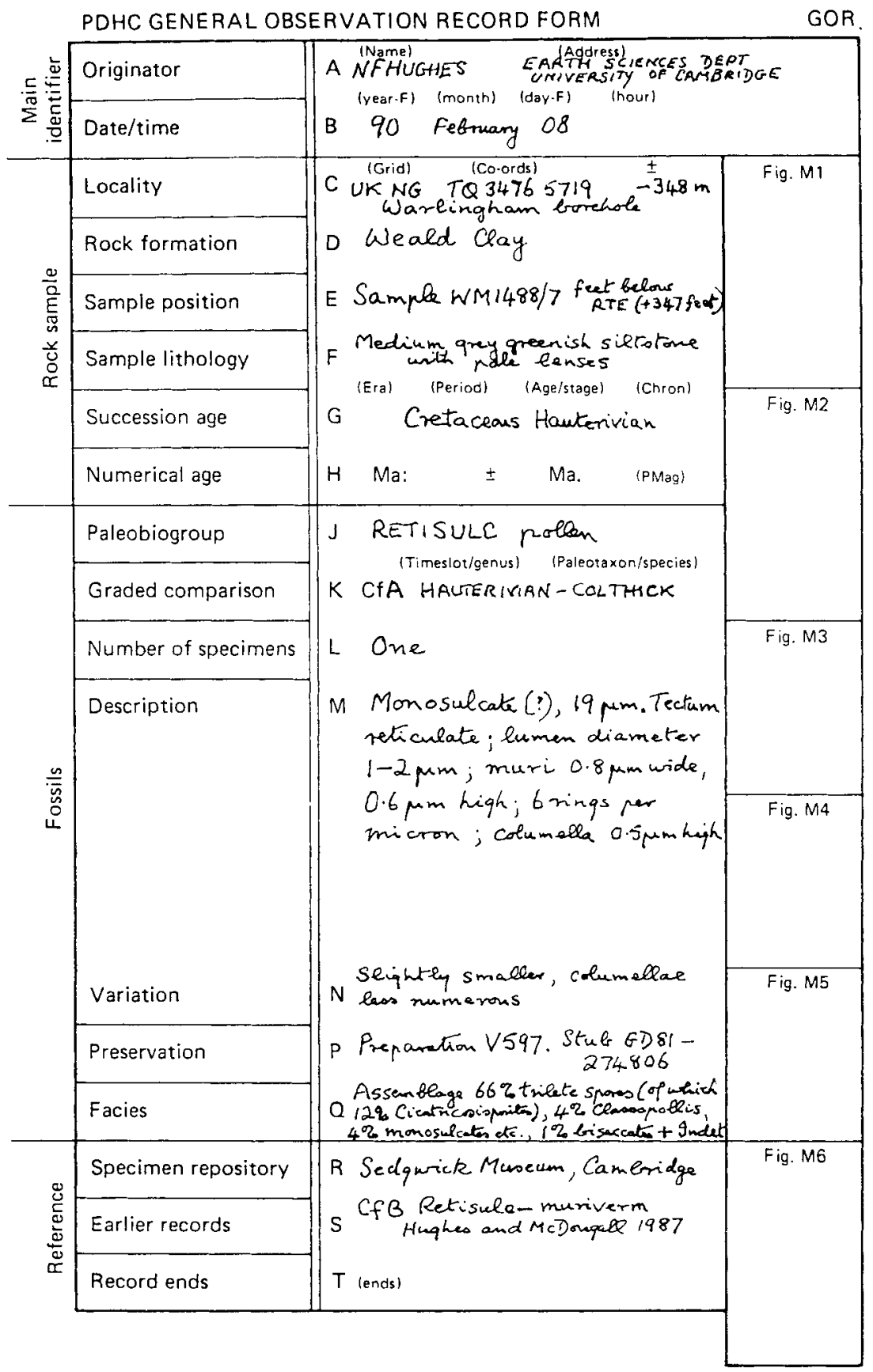

Fig. 2. Observation record (GOR form) for revised Retisulc pollen record CfA Hauterivian-colthick from Warlingham borehole (WM1488/7).

\section{Explanation of Plate 2}

Palaeotaxon Hauterivian-Colthick: scale bars 1 micron; 10 microns Figs 3 and 5. Figs 1-2. Specimen F; stub AM593-335731.

Figs 3-4. Specimen H: stub AM593-241805.

Figs 5-6. Specimen $\mathbf{J}$; stub AM592-330751.

Figs 7-8. Specimen K: stub AM593-331815. 

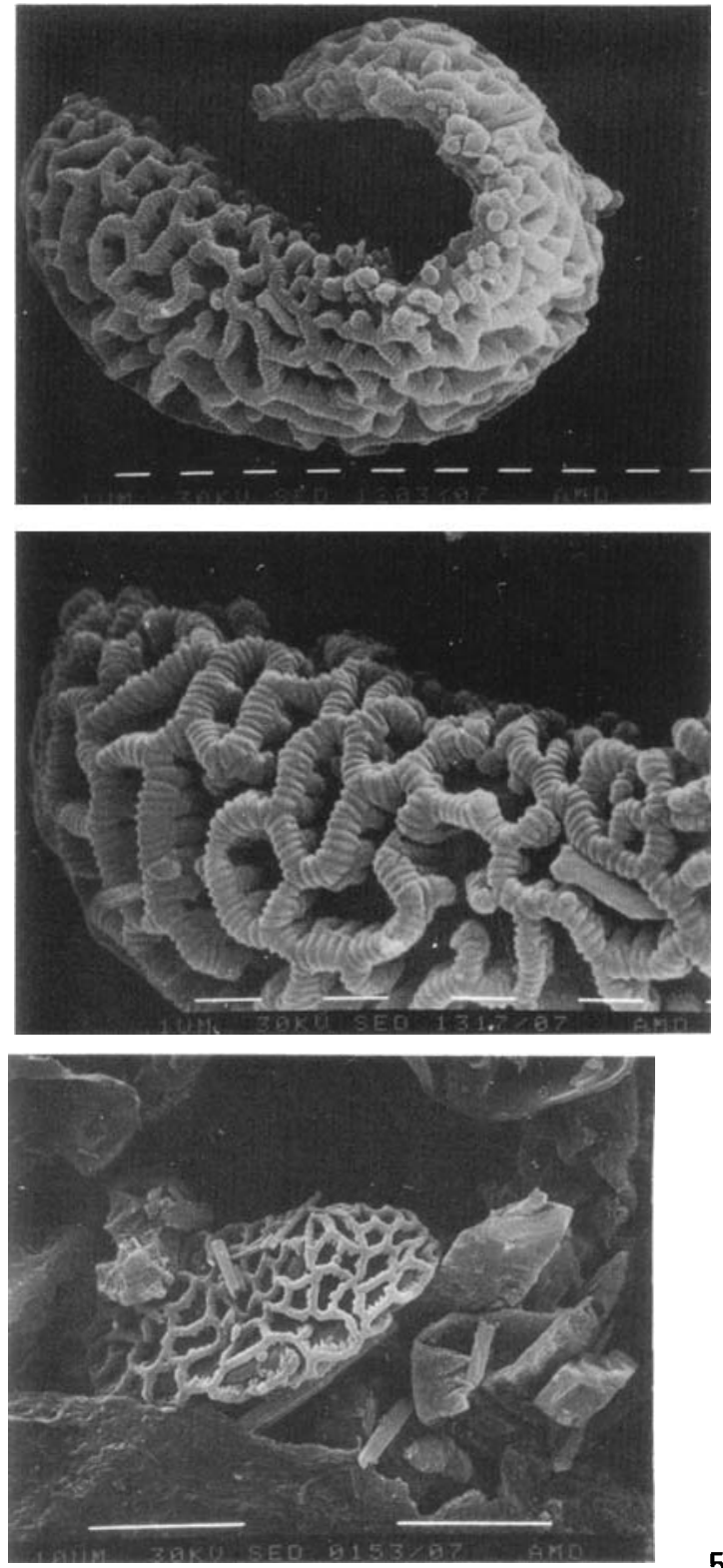

2

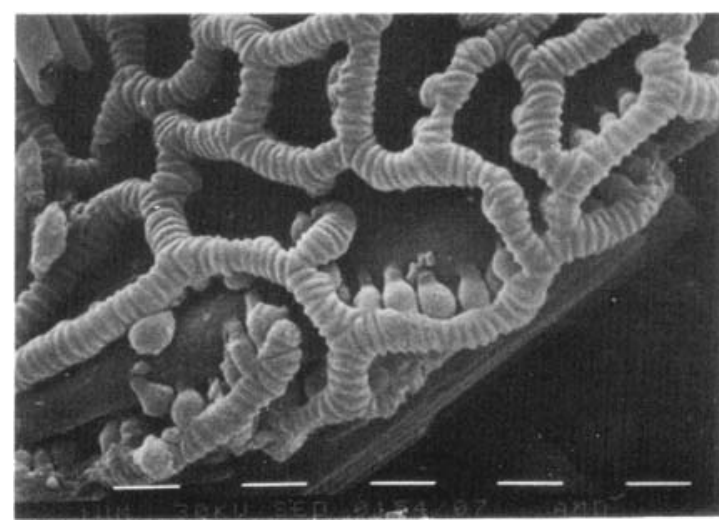

5

6
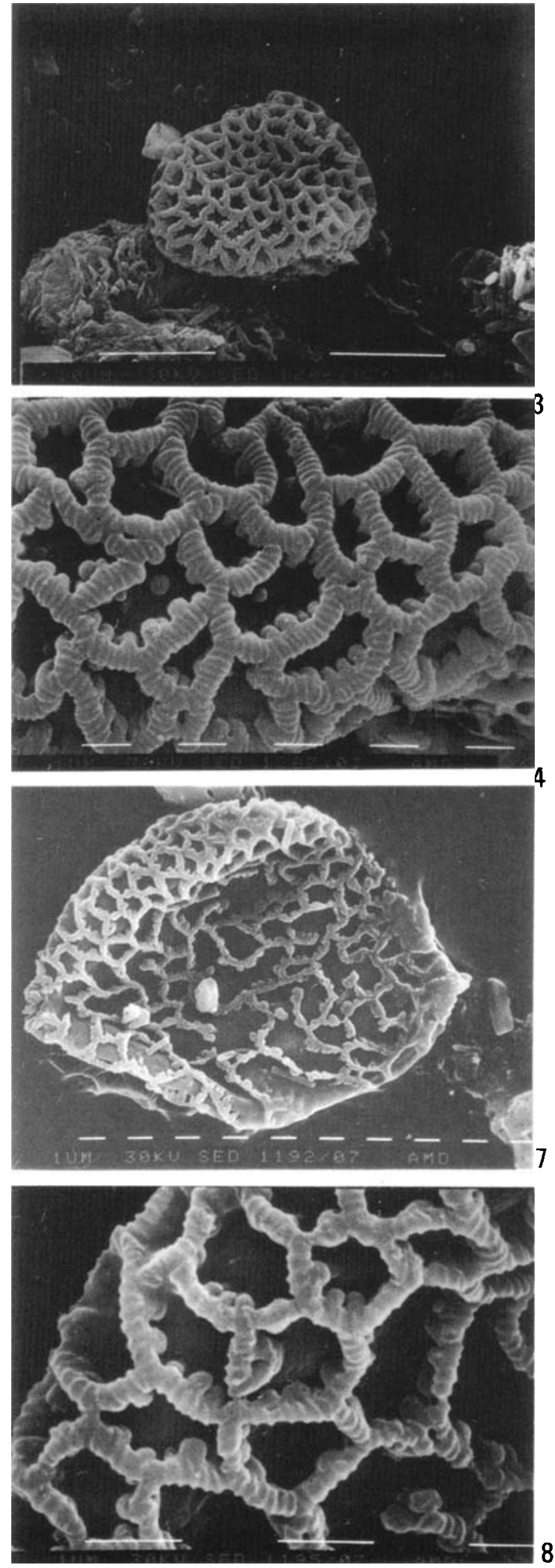
KINGSCLERE

WARLINGHAM

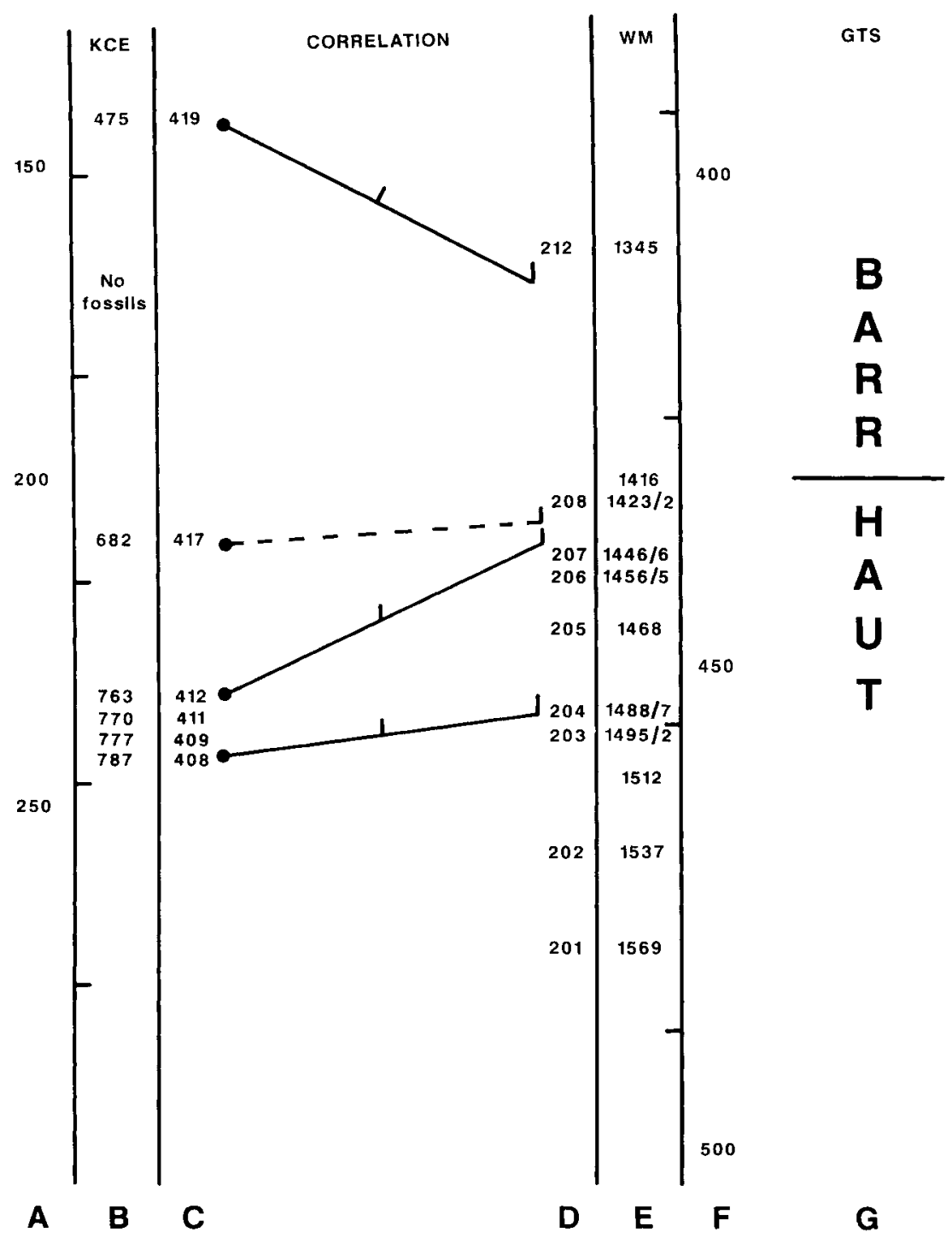

Fig. 3. Diagram to illustrate the evidence for succession dating of the Kingsclere borehole sample KCE 777. Columns: A-C, Kingsclere borehole. A, Depth in metres below RTE of rig. B, Samples in borehole (depths in feet). C, Event numbers relating to palynomorph assemblages. D-F, Warlingham borehole. D, Event numbers from palynomorphs (from Hughes and McDougall, 1990). E, Samples in borehole (depths in feet). F, Depth in metres below RTE. G, Hauterivian-Barremian boundary taken between samples $1423 / 2$ and 1416 in the Warlingham borehole (Hughes and McDougall, 1990).

Explanation of Plate 3

Figs 1-2. Palaeotaxon Hauterivian-Colthick; Specimen E; stub AM952-322823: scale bars 1 micron.

Figs 3-8 Assemblage, representative specimens: scale bars 10 microns.

Figs 3-4. Pilosisporites trichopapillosus Del. et Spr. 3, Distal aspect; stub AM592- 313733. 4, Proximal aspect; stub AM 592-313770.

Fig. 5. Aequitriradites spinulosus Cookson and Dettman; stub AM592-250762.

Fig. 6. CfA Hauterivian-cactisulc Hughes and McDougall 1987; stub AM592-280818.

Fig. 7. Concarissimisporites varierrucatus (Couper) Brenner; stub AM592-265775.

Fig. 8. 'Ephedripites' sp.; stub AM592-335747. 

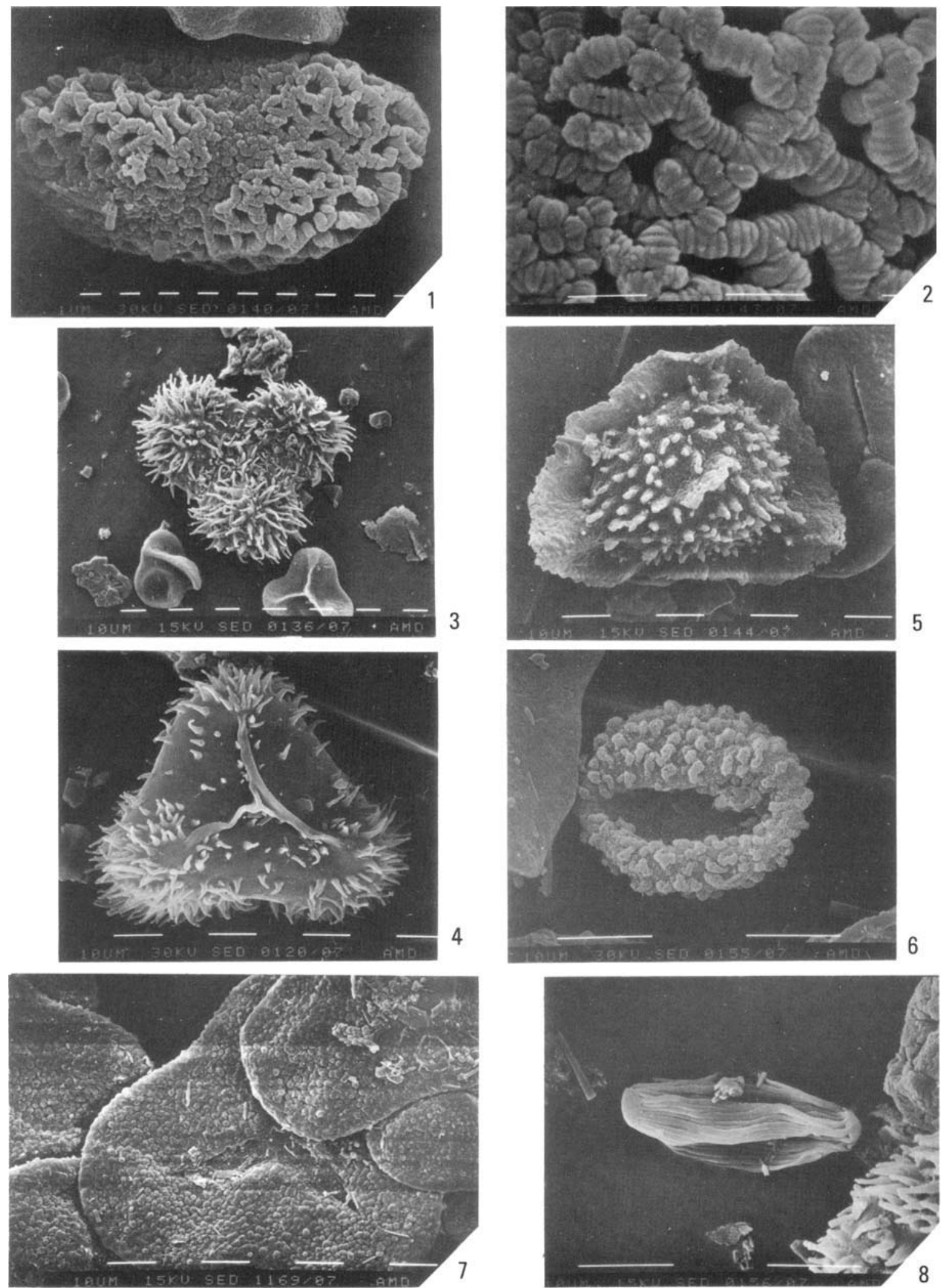
Sample WM $1423 / 2$ marks the entry of CfA Retisulcdentat and others in the reference succession (see Hughes et al., 1979); these pollen grains occur in quantity, and are clearly lacking in the assemblage KCE 763. They are also lacking in sample KCE 682, but no palynomorphs are common at this level. There are no KCE samples available above this until KCE 475 which contains abundant crotonoids and other Retisulc pollen of a distinct palynoflora which begins (Fig. 3) in the Warlingham borehole with WM 1345.

\section{PALAEOBIOLOGIC SIGNIFICANCE}

The aperture structure observed in these HauterivianColthick pollen grains is simple, as befits their early occurrence. The aperture membrane is thinner than the non-apertural footlayer (plus nexine) although continuous with it; the membrane curls or collapses inward in the dry grain. The general reticulate tectum of the grain breaks down over the aperture to small equidimensional tectal fragments with sculpture similar to that of the muri and also supported on individual columellae. The aperture with these tectal mural fragments (TMF) resembles the 'granular aperture type' of Albian reticulate monosulcates (Chapman, 1987) and also several Barremian biorecords (Hughes et al., 1979). In extant pollen, this type of aperture seems only to arise during the later stages of pollen wall development (Rowley, 1959; Horvat, 1966); the foot-layer and columellae develop all over the grain, and the position of the aperture is only apparent once the tectum begins to form as a reticulum. Only fragments of reticulum develop over the scattered columellae of the membrane, giving a somewhat disorganised appearance as a result of a process which seems not to be tightly controlled. It is interesting that in pollen-grain specimen C (Plate 1, figs 1-5) and two others, isolated baculac occur scattered on the foot-layer within the lumina of the general reticulum. This may suggest that the very open reticulum has evolved from a much denser state with smaller lumina which would have shown much less contrast with the aperture.

The other main aperture structure in early pollen is of the 'muri-bordered' type, in which the aperture membrane is a narrow strip of thin foot-layer edged with muri and columellae but itself devoid of sculpture. Examples are to be seen in the roof-muried taxa of Chapman (1986), the 'Retimonocolpites complex' (sensu Doyle et $\mathrm{al}, \mathrm{1975}$ ) and the biorecord Retisulc-dubdent (Hughes et al., 1979). Extant pollen studies (Angold, 1967) suggest that in this case, the aperture position, shape and structure are determined early in pollen wall development as an area where columellae are not formed. This muri-bordered aperture appears to require control of the whole of pollen wall formation from the first prenexine template.

What is not clear is why this earliest pollen should possess apparently segmented muri, when most of the monosulcate successors in Barremian rocks do not, with the exception of the crotonoid and some other forms which appear later. Thus far, search in earlier Hautcrivian and Valanginian rocks in Britain has not revealed precursors; tectate columellate grains reported by Trevisan (1988) from rocks of these ages in Italy are of types with simple muri similar to those of Barremian age in Britain. Walker and Walker (1984) figure, with their excellent techniques, some Barremian-Aptian grains of the TMF type (see above) from the Potomac Group; they choose to refer to them as Clavatipollenites although there is no close resemblance to the relevant holotype, and they regard them as 'relatively advanced' and therefore not indicative of the early evolution of angiosperms.

We are of the opinion that the adequately quantified and dated occurrence of Retisulc-Hauterivian-colthic pollen described above should not be considered either 'primitive' or 'advanced', despite the elaborate appearance in the tectum. The strength of this record encourages the belief that the occurrence of Retisulcmuribeaded from Warlingham (WM 1465; Hughes and McDougall, 1987), although only of isolated specimens, may also be significant. Search for precursors in continuous successions below these occurrences has not yet yielded any candidates differing markedly from those described by Hughes and McDougall (1987).

\section{Manuscript received March 1990 \\ Revised manuscript accepted February 1991}

\section{REFERENCES}

Angold, R.E. 1967. The ontogeny and fine structure of the pollen grain of Endymion nonscriptus (L.). Review Palaeobotany Palynology 3, 205-212.

Chapman. J.L. 1986. Practical difficulties in the application of the species concept in Albian angiosperm pollen. Special Papers in Palaeontology 35. $41-53$.

Chapman, J.L. 1987. Comparison of Chloranthaceae pollen with the Cretaceous 'Claratipollenites complex': taxonomic implication. Pollen et Spores 29 (2-3). 249-272.

Couper, R.A. 1958. British Mesozoic microspotes and pollen grains Palaeontographica B, 103, 75-179.

Doyle, J.A., Van Campo, M. and Lugardon, B. 1975. Observations on exine structure of Eucommiidite's and Lower Cretaceous angiosperm pollen. Pollen et Spores 17 (3), 429-486.

Horvat, F. 1966. Contribution a la connaissance de l'ultrastructure des parois du pollen de Tradescamia paludosa L. Grana palynologica 6 (3), 416-434.

Hughes, N.F. 1989. Fossils as information. Cambridge University Press, 136pp.

Hughes, N.F., Drewry, G.E. and Laing, J.F. 1979. Barremian earliest angiosperm pollen. Palaeontology 22, 51 3-535.

Hughes, N.F. and McDougall, A.B. 1987. Records of angiospermid pollen entry into the English Early Cretaceous succession. Review Palasobotany Palynology 50 $255-272$

Hughes, N.F. and McDougall, A.B. 1990). New Wealden correlation for the Wessex Basin. Proceedings Geologists Association 101 (1) 85-90.

Kemp, E.M. 1968. Probable angiosperm pollen from British Barremian 10 Albian strata. Palaeontology 11, 42 [-434.

Kemp, E.M. 1970. Aptian and Albian miospores from Southern England Paleoniographica B 131, 73-143.

Rowley, J. 1959. The fine structure of the pollen wall in Commclinaceae. Grana palynologica 2 (1), 3-31.

Trevisan, L. 1988. Angiosperm pollen (monosulcate-trichotomosulcate phase) from very early Lower Cretaceous of Southern Tuscany, Italy. Abstracts 7 International Palynological Congress, Brisbane. 165.

Walker, J.W. and Walker, A.G. 1984. Ultrastructure of Lower Cretaceous angiosperm pollen and the origin and early evolution of flowering plants. Anmals Missouri Botanical Garden 71, 464-521. 